1. Вовлечь в процесс социализации и управления траекторией развития талантов и способностей молодежи большее количество представителей разновозрастных групп подрастающего поколения региона.

2. Решить вопрос необходимой дебюрократизации в процессе работы с молодежью.

3. Более эффективно и оперативно выявлять таланты и способности молодежи.

4. Целенаправленно планировать и управлять траекторией развития талантов и способностей молодежи на уровнях модулей МАС: «Школа», «Университет», «Гагарин-центр», «Корпорация».

5. Оптимизировать процесс популяризации Сaмарской области как крупного и успешного научнообразовательного центра России.

\section{СПИСОК ЛИТЕРАТУРЫ:}

1. Смирнов С.В. Онтологии как смысловые модели // Онтология проектирования. 2013. № 2 (8). C. $12-19$.

2. Виттих В.А. Введение в теорию интерсубъективного управления. Самара: СНЦ РАН, 2013. 64 с.

3. Андрончев И.К. Формирование и развитие организационно-экономического механизма конкурентоспособности современных вузов // Вестник Самарского государственного университета. 2015. № 5. (127). С. 188-193.

4. Постановление Центрального Совета Профсоюза от 27.10.2010. № 2-11.

5. Франк С.Л. Реальность и человек. Метафизика человеческого бытия. Париж, 1956. 416 с.

\title{
PARTICIPATION OF PROFESSIONAL ASSOCIATIONS OF EDUCATORS IN THE PROJECT «SOCIALIZATION AND MANAGEMENT OF THE SAMARA REGION YOUTH TALENTS AND ABILITIES DEVELOPMENT TRAJECTORY»
}

(C) 2017

Andronchev Ivan Konstantinovich, doctor of technical sciences, professor of Electric Transport Department Popova Natalia Ivanovna, senior lecturer of Personnel Management Department

Popov Dmitry Alexandrovich, candidate of technical sciences, associate professor of Natural Sciences Department Samara State Transport University (Samara, Russian Federation)

Abstract. The following paper deals with socialization of the Samara Region youth in the direction of the modern younger generation talents and abilities development. The authors consider modern social environment as a basis of a young person's identity formation which directly influences his/her character. The authors offer to change methods of social interaction between public organizations and public authorities to increase their effective functioning. For this purpose, they analyze the work of public associations of educators of Samara. The authors offer to use a communicative (intersubjective) way of interaction of all participants of the process which is based on horizontal interaction where each interested party carries out a function within the competence by equal participation. As a result, joint activity gains a character of a community. This kind of interaction increases each participant's ability to solve joint problems of any complexity, increasing at the same time abilities of others. Using a technology of multi-agent automated systems (MAS) in planning and management of the youth talents and abilities development trajectory, the most effective result in collaboration of public organizations and public authorities can be achieved.

Keywords: socialization; younger generation; development of talents; education; science; social environment; public organizations; professional associations; state; interaction; theory of intersubjective management; multi-agent technologies; potential; efficiency.

УДК $167.7+37.035 .6$

\section{ФИЛОСОФСТВОВАНИЕ КАК ПЕДАГОГИЧЕСКАЯ ТЕХНОЛОГИЯ: ЕВРОПЕЙСКИЙ И РОССИЙСКИЙ ОПЫТ}

(C) 2017

Бакшутова Екатерина Валерьевна, доктор философских наук, доцент кафедры общей и социальной психологии

Самарский государственный соџиально-педагогический университет (2. Самара, Российская Федераџия)

Аннотация. В статье доказывается, что философствование является одной из наиболее эффективных педагогических технологий развития личности и общества, актуализирующей возможность и способность к порождению нового знания о мире и человеке, которое, в свою очередь, во многом определяет человекосообразность интеллектуальных и реальных социальных коммуникаций, в том числе и образовательных. Показано, что знание приносит ощутимую пользу тогда, когда оно становится предметом и частью публичной интеллектуальной коммуникации, в том числе философии, педагогики и социальных практик. Представлена авторская интерпретация истории философствования в топосах интеллектуальных дискуссий: город - монастырь - город - университет, обобщен сравнительный анализ принципов философствования западных и российских философских школ. Выявлена специфика философствования в российском интеллектуальном пространстве, в том числе - образовательном, вытеснение философствования из школы и университета в свободные творческие сообщества - кружок либо салон. Описаны различия в педагогической направленности европейских и российских философских школ и традиций, когда в европейском опыте в качестве «обучающихся» выступали «верхи», а в российском - философствование как педагогическая технология в XIX начале XX в. было ориентировано на «низы», но в любом случае оно всегда являлось практико-ориентированным. Делается предположение о том, что в обоих случаях ограничение учебной аудитории излишне, что 
особенно очевидно в современных условиях доступности образования, из которого довольно часто свободное философствование выхолащивается.

Ключевые слова: философствование; индивидуальное и коллективное философствование; педагогическая технология; гуманитарное пространство; образовательное пространство; публичная философия; топосы философствования; созидание знания; догматизм и авторитаризм в философской школе; свобода интеллектуальной деятельности; общественная значимость гуманитаристики.

Философствование можно рассматривать как имманентный человеку процесс познания - не случайно в научной литературе рассматривается проблема детского философствования и философской пропедевтики [1]. В то же время философствование - это отнюдь не интуитивный и стихийный процесс, философствование - определенный уровень в отражении мира, причем достаточно высокий уровень, опирающийся на предшествующий путь мышления человечества, на онтологию и гносеологию, т.е. форма мышления, требующая определенных методов и сама же эти методы порождающая; для философов же философствование есть «профессиональное ремесло мышления» [1, с. 435]. Возникает вопрос: может ли философствование быть групповым, коллективным или оно представляет собой процесс сугубо индивидуальный? Что дает нам основания рассматривать философствование не просто как познавательный процесс, но как практическую, гуманитарную, педагогическую технологию?

Несомненно, что обыденное философствование, доступно большинству, но некоторые одарены способностью философствовать в большей степени, чем другие, и также они могут быть одарены способностью вовлекать в круг своих идей учеников, обучать их не просто философии как знанию, но и философствованию как процессу созидания знания. В обыденных представлениях философствование часто предстает как простое и доступное всем умение «порассуждать», что свидетельствует о пренебрежительном отношении в нашем обществе к философии и процессу ее создания. Для этого есть причины, обусловленные историческим опытом философии в нашем обществе, о чем мы скажем ниже более подробно. Однако очевидно то, что свободное философствование, да и свободное рассуждение было небезопасно, но и направлялось в «нужное русло» бюрократическими регламентами, что привело к утрате способности свободно мыслить, создавая новое, прежде всего, гуманитарное знание. В действительности же, во-первых, в основе философствования лежит такая компетентность как «критическое мышление», требующая специальных навыков, обучения им и тренировки [2]. Во-вторых, для формирования такой компетентности требуется еще одно важное условие, собственно практико-ориентированное запрос государства и общества на специалистов, способных мыслить критически.

Философствование индивидуально, но и коллективно, поскольку «философские концепции и способы философствования ... образуют сложные цепочки и плетения, в которых каждое из звеньев пересекается с близлежащими, цепляется за них, но при этом может не иметь никаких непосредственных связей с другими, может никак к ним не относиться или иметь сложно опосредованные переходы к ним» [3, c. 102].

Естественно предположить, что один философ не сможет создать такой сети, хотя имя первого фило- софа нам известно. К счастью, в этом занятии он не остался в одиночестве. Философия создается и существует благодаря множеству отдельных философов. В то же время философия, как и любое знание, «сознание», смысл, не существуя без каждого отдельного философа, коллективна: «философия не просто мышление, а "со-мышление", т.е. такое мышление, которое предполагает мыслящее общение людей или мышление людей сообща» [4]. Согласимся с тем, что «философия - коллективное мышление, так же как наука - коллективное познание, искусство - коллективное чувствование, религия - коллективное верование, мораль-политика-право - коллективное воление, экономика - коллективное производство-распределение и т.д.» [4]. Добавим, что образование коллективная практика культурации личности и творения социально значимых смыслов и ценностей.

Неслучайно выделяемые в философии типы и формы философствования соотнесены с территориями, историческими периодами, культурами, т.е. с коллективным философствованием: например восточный и западный тип философствования, античный и средневековый, рациональный и иррациональный, дорефлексивная стадия философствования и рефлексивная и т.д. Существует классификация типов философствования, предлагаемая в учебниках и ресурсах для студентов: созерцательный - характерный для Античности; умозрительный - поздняя Античность, Средневековье, русский религиозный ренессанс; деятельностный, связываемый с философией марксизма; новейший, социально-экологический тип философствования (учение В.И. Вернадского о ноосфере, еще ранее - идеи Н.Ф. Федорова о сознательной регуляции человеком природы, теоретические заключения «Римского клуба»). Общепризнанно деление по типу рациональности, а значит, и по сложности мыслимых объектов и самого мышления. Тип философствования «спускается» от социального макросубъекта к индивиду через малые группы - семью, сообщество сверстников, школу, университет и т.п. Существуют и специальные (специализированные) малые группы для философствования. И здесь мы воспользуемся метафорой М.Н. Эпштейна, разводящего в разные стороны научный симпозиум и платоновский симпосион [5, с. 269].

Мы полагаем также, что динамична и топология философствования, связанная с «местом» философствования. Это город (Античность) - монастырь (Средневековье) - город (Возрождение). А с наступлением Нового времени начинается разветвление и специализация культурных практик философствования: монастырь - университет, салон, кружок. Наряду со сменой этих культурных форм, в которые вписывается философствование вместе со всеми правилами, предъявляемыми различными институциями, существует и более важная основа выражения и передачи гуманитарного знания - появление письменности и письменной ментальности и уже внутри нее - книжности, т.е. переход от индивидуального само- 
выражения в слове в Древней Греции к массовому квазивыражению в современный период с помощью технических устройств. Письменность сохраняет культуру мысли и дает возможность включать в поле диалогов широкий круг мыслителей и их текстов, которые несут в себе «социальный код возникновения мира через конфигурирование таких его онтологических составляющих, как телесность, местность и совместность, происходящих в процессе регулярного телесного взаимодействия между людьми посредством какой-либо социальной практики, благодаря которой порождается определенное "со-общение" (само это повествование), способствующее "приобщению" людей к своему "со-обществу" с определенными представлениями и ценностями» [6, с. 9].

Несомненно, прав Б. Рассел, начиная свою «Историю западной философии» со слов: «Во всей истории нет ничего более удивительного и ничего более трудного для объяснения, чем внезапное возникновение цивилизации в Греции» [7, с. 21]. Из истории философии Древней Греции мы знаем о существовании многих школ: римские историки насчитали в Древней Греции «288 философских учений, из которых помимо великих философских школ выделяется учение киников и киренских философов. В 306 году афиняне издают закон, запрещающий под страхом смертной казни открывать новые философские школы. И хотя через год его отменяют, в Афинах остаются четыре большие школы: Академия Платона, Ликей Аристотеля, Портик (стоическая школа) и Сад (эпикурейская школа). Мы считаем первым философом Фалеса, а вообще, как известно, «философ» как самоназвание использовал Пифагор. «Основная заслуга Фалеса была не в ответах, а в вопросах, которые он поставил. Ответы не могли быть достаточно удовлетворительными, поскольку вопросы были безнадежно трудными. Откуда Фалес мог знать, что было началом мира? Необходимо допустить, что первый философ был выдающимся человеком ... переход от умений к философии, может быть, и не требовал больших умственных усилий, но сам поступок был достаточно смелым» [8, с. 36]. Для нас это важный момент, т.к. философствование - это именно искусство вопрошания. А.Ф. Лосев этот период ранней классики называет «интуитивной философией» [9]; мы бы охарактеризовали его еще и как деятельностную философию, поскольку школы, т.е. ученики этого периода, должны были жить «по образу и подобию» учителя, руководителя школы.

Во второй период античной философии продолжает развиваться философия природы, существует школа Демокрита, активны пифагорейцы. Однако философия становится другой. В нее включаются персонажи средней и высокой классики: софисты, в среде которых выделяется Протагор; Сократ; киники и киренаики - общие ученики софистов и Сократа; Платон; Аристотель. В софистах мы узнаем вполне современную нам интеллигенцию, или интеллектуальную элиту общества, - они учили детей и взрослых, сами были «говорящей» группой и выполняли общественные функции. Не менее «знакомой» выступает ситуация преследования софистов, которое пришло на смену благосклонному отношению к ним общества. Кстати, в свое время еще над Фалесом современники потешались из-за того, что философия не приносит дохода. Фалес нашел способ быстро разбогатеть, чтобы показать, что и философ может быть богатым, правда, это не были занятия философией. Софистов же, напротив, обвинили в том, что они за свою работу берут деньги - это для греков было унижением умственного труда. Кроме того, их обвиняли в том, что, обучая, они нарушают веру и традиции. В том числе и Платон боролся с ними, «не выбирая средств» [8, с. 54].

Как о важной ступени в развитии архетипа философа и философствования говорим мы о Сократе, который представляет собой образец служения, следуя парменидовскому «человек - мера всех вещей»: «ОН был тем человеком, в личности которого мыслитель и гражданин неотделимы друг от друга. Когда того требовали обстоятельства, он служил солдатом, во время войны являя примеры мужества, а во времена мира - примеры рассудочности и гражданской отваги... Его деятельность основывалась на обучении людей добродетели, а точнее говоря, Сократ учил их разуму, чтобы через разум привести к добродетели» $[8$, с. 54$]$.

Очевидно, что пролегомены группового философствования, которые мы обнаруживаем у российской интеллигенции, имели место уже в античную эпоху. Неинституализированные философы осуществляли свою деятельность собственно в городе, то есть не только в общественных институтах и учебных заведениях, но и просто на улице, что мы увидим и в России, правда, здесь не улица, а научный или литературный салон, кружок.

В Античности интеллектуальная деятельность считалась престижной до такой степени, что в глазах общества не требовала вознаграждения, но в то же время была и средством пропитания (у софистов). Правда, для российской ситуации второе важнее и имеет коннотации, связанные не столько с интеллектуальной деятельностью, сколько с образованностью и наличием диплома об образовании - особенно в тот период, когда интеллигенция начинает формироваться как целое сословие. Как пишет В.А. Шкуратов, «в пореформенные десятилетия критерий образованности распространяется вглубь российского общества, становится общепринятой оценкой. Комическую сторону новой социализации рисовал ранний А.П. Чехов. Человек старой закваски знает, что «философствовать может только образованный человек, который курс кончил». Самозванца, который без гимназического аттестата «верите ли, газету, каналья, выписывал!», он неоднократно (за разговоры «про Бисмарка, да про разных там Гладстонов», «за русско-турецкую войну») «по зубам бил». Но остановить неподобающее времяпровождение не удается. Герои чеховских интермедий находятся «в постоянных выяснениях, кто образованный, а кто необразованный, имеет ли право рассуждать или нет, какая образованность бывает и что она дает, в забавных самоаттестациях» $[10$, с. 245]. Близок этому и феномен интеллектуального снобизма, который проявляется у античных философов, - Пифагор считал себя равным богам, а Платон считал, что брать деньги за просвещение - грех (как мы знаем, он был состоятельным человеком).

В Античности возникает проблема интеллектуальной честности - не совсем в современном значе- 
нии, принятом в науке. Проблема возникает в конфликте Протагора и Платона относительно понимания истинности доказательства (для Горгия и других софистов важно было следовать за доказательством, куда бы оно ни привело, для Платона же истинность доктрины оценивается по ее социальному значению, т.е. добродетели). И в этом смысле российская интеллигенция следует Платону, т.к. ее философствование социально ориентировано.

Также мы видим предысторию проблемы догматизма и диалогизма в философствовании, актуальной для российской интеллигенции и в настоящее время. Напомним, что в школе Пифагора знание считалось общим достоянием (как появившееся диалогически), но вместе с тем члены сообщества должны были строго следовать установленным Пифагором правилам («Сам сказал»).

Возможность критики как составляющая интеллигибельности в целом и как групповая дискурсивная характеристика также порождаются в период Античности (школы появляются одна в рамках другой как проявление эволюции философских взглядов учеников и несогласия с учителем).

Античная философия передала форму философствования христианству, именно форму. В частности, античное «наследие» философствования можно связать с первыми христианскими ересями, отличительной особенностью которых были рассуждения по поводу самых сложных и труднодоступных пониманию мест Писания.

Догматическое религиозное философствование начала новой эры, патристика - философия и теология отцов церкви - распределились в оппозиции Восток - Запад. С одной стороны это Ориген, Григорий Нисский, Тертуллиан, псевдо-Дионисий, Иоанн Дамаскин и др., которые тяготели к соединению христианской веры и греческой науки. Труды средневековых философов, несмотря на религиозную подоплеку, имели прикладной, социально ориентированный характер - св. Амвросий обосновал церковную концепцию независимости церкви от государства; св. Иероним дал западной церкви латинскую Библию, заложил традиции монашества и прославился тем, что писал множество наставлений по сохранению девственности; св. Августин выработал теологию церкви, действовавшую до Реформации и составившую основу лютеранства и кальвинизма. Это была собственно западная философская система, уже свободная от греческого влияния и наиболее соответствовавшая вере.

И второй период средневековой философии, схоластика, получив от отцов церкви набор догматов и понимание того, что с содержанием философствования все определено и определенно (поскольку в центре всего Бог), уделяет внимание более всего формально-логическим аспектам философствования, а также спорам между идеализмом и реализмом, фидеизмом и эмпиризмом, диалектикой и мистикой, интеллектуализмом и волюнтаризмом.

Философствование перемещается из общин и с городских улиц в монастырские, епископские и королевские школы, где также преподавали духовные лица. Эта традиция передачи и сохранения знаний характерна и для российской истории до определенного времени.
Но в раннем Средневековье мы видим скорее отличия интеллигибельности на Западе от той, которая в дальнейшем разовьется в России, - западное христианство добилось в течение нескольких столетий независимости от греческой философии, и кроме того, философы-схоласты зачастую вырабатывали собственную методологию и систему доказательств своих идей. Т.е. индивидуализм как основа либерализма коренится в религиозной христианской философии.

Архетипическим примером публичного философского самовыражения служит спор об общих объектах, о природе всеобщего, или об универсалиях, возникший еще в Античности и актуализировавшийся в конце XI и первой половине XII веков. В Средневековье спор номиналистов и реалистов не столько апеллировал к работам античных авторов, которые его начали, сколько был воспринят уже дискурсивно - через переводы, комментарии и труды Порфирия и Боэция. Реализм для средневекового философатеолога был естественен, он утвердился как бы сам собою, без дискуссий. Споры начались тогда, когда появился номиналистический антиреализм, и стали явными в XII веке, который целиком был посвящен поиску философского компромисса.

Интересно взглянуть на функцию философии в этот период ретроспективно по отношению к Новому времени. Судя по тому, о чем писал Абеляр, философия не совсем была «служанкой богословия» - в схоластике рассматривались и реальные объекты, и методы мышления о реальности (и так как помимо Священного Писания не существовало ничего непогрешимого, то спорить можно было обо всем). В спорах средневековых философов формировался свободно мыслящий субъект, не просто открывающий по благословению тайны природы или божественных сущностей, а постигающий их в процессе собственной мыслительной деятельности. «Между наукой Средневековья и наукой Нового времени происходит превращение схоласта, использующего свои мыслительно-созерцательные способности в качестве творения и раба Божьего, в субъектаисследователя, свободного от религиозно-онтологических забот, но обязанного быть корректным в лабораторных процедурах и обосновании гипотез. Это происходит не сразу» [12, с. 71]. Уже Абеляр приходит к тому, что «процесс познания всегда начинается с ощущения, но образы вещи, которые даются чувствами и воображением, являются только материалом для понятийного познания. Разум путем абстракции выделяет из них особые элементы и создает общие представления» [8, с. 169].

В XIII в. появляются новые организационные формы для интеллектуальной работы в целом и для философствования в частности: университеты (философия была подготовительным этапом в образовании теологов, правоведов и медиков; философ, начиная учиться в университете, мог там же преподавать и прекращал преподавание философии для того, чтобы учиться теологии) и монашеские ордена, особенно доминиканский и францисканский, которые благодаря всеобщей забастовке преподавателей в 1229 г. получили кафедры в Парижском университете. Монашество привлекается к научной работе. В 1271 г. Роджер Бэкон мог написать «лишь с небольшим пре- 
увеличением, что все достигнутое в теологии и философии за последние сорок лет было результатом деятельности монашеских орденов» [8, с. 184]. В результате между орденами состоялся философский спор, а также шла борьба еще и с духовенством, не входившим в ордена, длившаяся с 1252 по 1259 гг. («борьба философов»).

Способ организации жизни и деятельности, научной и педагогической, необходимость проработки определенных задач (выявление и категоризация антиномий, уточнение смысла античных текстов, спор о первичности идеи и реальности), воспринятых от античной традиции философствования, обусловили то, что в монастырях коллективное мышление преобладало над индивидуальным. Вся работа была «привязана» к текстам, их осмысление и комментирование осуществлялось как в письменной, так и в устной форме, в виде свободных торжественных диспутов и дискуссий, конспекты которых также составлялись и комментировались.

Для сложной и многогранной эпохи Возрождения главной идеей является идея воспитания и образования человека. Вот что пишет П.О. Кристеллер: «Гуманизм эпохи Возрождения не был философской системой, это была скорее культурная и педагогическая программа, которая разрабатывала важный, но ограниченный сектор знания. Этот сектор имел в качестве своего главного центра группу предметов, которые касались в основном не классических наук или философии, но того, что приблизительно может быть названо литературой» [цит. по: 11]. От Средних веков была воспринята традиция диспутов и споров, но предмет спора изменился. Кстати, нельзя сказать, что «возвращение» философствования на улицу сделало его более демократичным, - у него остались также эзотерическая и обыденная составляющие.

Еще раз обратим внимание на то, что публичное философствование европейских интеллектуалов, даже будучи социально ориентированным, связанным с воспитанием и педагогикой, было ориентировано на «верхи» - правителей, богатых горожан, образованных монахов, ученых и т.п. Это был в целом «свой» круг при всех разногласиях в сферах форм и содержания обсуждаемых проблем. Философствование в Европе не пострадало даже от мистицизма, и хотя для подготовки почвы ньютоновской механике потребовались и костры инквизиции, рациональное в ней было укоренено очень глубоко, именно на уровне метода. Кстати, французский писатель Лабрюйер (1645-1696 гг.) в XVII в. начал говорить о крестьянах, но, по словам Ж.-П. Сартра, «он пишет не для них. Когда он отмечает факт их бедственного положения, то это не довод против идеологии, с которой он совершенно согласен, а в поддержку этой идеологии: это позор для просвещенных монархов, для милосердных христиан. Так он общается с массами через их голову. Эта книга, конечно, не способствовала росту их самосознания» [290]. Таким образом европейский интеллектуал показывает власти ее образ (точно так поступали и средневековые отцы церкви).

В эпоху Возрождения благодаря новым идеям в университетах стали давать светское образование. Появляется новая научная институция - журнал, т.е. новая культурная практика философствования. В
XVII в. в каждом университете издавался собственный журнал. В Новое время в системе образования появляются кружки и академии.

Согласно теории интеллектуальных сетей Р. Коллинза, интеллектуальная коммуникация имеет отличительные черты. Прежде всего «сакральным объектом» интеллектуальной коммуникации выступает «истина»: «истина трансцендентна по отношению к индивидам, объективна, имеет принудительный характер и требует уважения» [цит. по: 13, с. 134]. Вовторых, интеллектуальные сообщества «обращены вовнутрь, ориентированы на обмен скорее между собственными участниками, чем с аутсайдерами». Втретьих, «интерактивный ритуал» интеллектуальных сообществ включает в себя «ситуации, когда интеллектуалы собираются вместе ради серьезного разговора, причем не направленного на социализацию и не имеющего практического характера» [13, с. 135]. Ключевым элементом интеллектуальных коммуникаций выступает «лекция или формализованный спор (диспут), т.е. некоторый отрезок времени, в течение которого один человек выступает с речью, представляя развернутую аргументацию по определенной теме». Внимание участников интеракции фокусируется на организованном таким образом «едином потоке рассуждений». Отношениям между выступающим и аудиторией (в том случае, если речь идет о реальной интеллектуальной коммуникации, а не о ее имитации) присущ состязательный характер. «Фундаментальная характеристика интеллектуальных структур состоит именно в том, что задаются вопросы и ведутся споры; также часто происходят взаимные опровержения в круговой структуре, напоминающей равным образом кольцо кула, потлач и вендетту. Даже когда интеллектуалы сидят молча, составляя аудиторию лекции или доклада, они осознают свою роль» [13, с. 135].

В Новое и Новейшее время философствование связано с университетами или представляет собой свободное, неинституализированное творчество. Шопенгауэр писал, что «университетская учеба была одним из возможных подходов к философии, тем самым впервые констатировав исторический факт огромного значения» $[14$, с. 63$]$. Вероятно, что специфику философствования здесь определяли именно организационные формы - университетская философия подчинена определенным государственным регламентам даже больше, чем она была подчинена в свое время церкви, т.к. в Средние века философы, даже монастырские, были еще и спорщиками, людьми публичными.

В «университетской революции» в Германии начала XIX в. (Берлинский университет) ученые, и прежде всего преподаватели философии, отвоевали себе существенные права внутренней автономии (так называемые академические свободы) и опробовали новую модель высшего образования, базировавшуюся на состязательных структурах (публичный диспут, диссертация и ее защита, конкуренция с другими профессорами и университетами за привлечение студентов), - модель исследовательского университета [15, с. 833-835]. Интересно, как изменилась ситуация с преподаванием в работе И. Канта, читавшего лекции до 1796 г. в Кёнигсберге, и Г. Гегеля, читавшего лекции до 1831 г. в Берлине: «Кант препо- 
давал различные предметы по учебникам, которые были написаны другими, и увековечил свою философию в книгах, которые никогда не составляли предмета или основы его преподавательской деятельности» $[14$, с. 63]. Разделение университетской и книжной форм было характерно для философии XVIII в., и Кант был одним из последних, кто работал в этой образовательной стратегии. Гегель, «имевший свои соображения по всем разделам философии, обозначил смену акцента. Он написал всего лишь две книги (не считая компендиума для своей "Энциклопедии философских наук" и "Философии права"): "Феноменологию духа" (1807 г.) как свое первое крупное сочинение и введение в собственную философию и "Науку логики" (1812-1816 гг.) как краткое изложение собственной мысли» $[14$, с. 63]. Для более глубокого ознакомления с мыслями Гегеля нужно было слушать его лекции. То есть живое знание вновь рождалось в аудитории, для живых слушателей.

Представляет интерес и сама университетская революция. По словам А.В. Нехаева, «намерения крупнейших философов периода "университетской революции" - Иммануила Канта, Иоганна Фихте, Фридриха Шеллинга - ее возглавить, инспирируя вокруг этого дискуссии и тем самым вербуя и мобилизуя своих сторонников в самых широких интеллектуальных кругах, выглядят вполне оправданными» [16, c. 83]. Несомненно, что преобразования в администрировании образования имеют собственно социальные аспекты, связанные с социальным и экономическим капиталом. Однако в связи с претензиями на формирование новых академических практик «философии требовалось сформулировать и представить идеологически подкрепленную исследовательскую программу, которая могла бы обеспечить для нее титульные права на владение территорией науки. Разумеется, подобного рода философская программа не заставила себя долго ждать. Идеи "Разума" и "Критики", открыто исповедуемые сторонниками кантовского трансцендентализма, как нельзя лучше подходили для этих целей, требовалось только придать им необходимые идеологические очертания» $[16$, с. 83]. Неслучайно четвертая часть «Критики» называется «Спор факультетов». Вопрос о приоритете философии над другими науками остро дискутируется, некоторые работы Канта вызывают недовольство короля Пруссии Фридриха Вильгельма II. Мы видим пример идеологического использования философии, провозглашения ее единственно возможной и необходимой для дифференциации полей других наук и внедрения стандартов рациональности (взамен теолого-богословских) в социальные практики. Несмотря на то, что у истоков университетской революции стояли отдельные философы-трансценденталисты - Кант, Фихте и Шеллинг, которые смогли представить идею как социальный институт (то, что постоянно происходило и происходит в России), сама революция - проект коллективный, результат группового философствования.

Университетская философия в России регламентировалась государством. В 1804 г., когда в Берлинском университете началась «революция», при университетах России были созданы цензурные комитеты, определявшие темы и источники для преподава- ния философии. «Чиновники в директивном порядке устанавливали, кто должен быть "авторитетом" для университетских философов. Вплоть до 80-х гг. XIX в. власти предписывали изучать в основном Платона и Аристотеля, и даже лекции профессуры 60-80-х гг. вращаются вокруг обсуждения тем великих греков. Если же по причинам необходимости преподавания современных дисциплин типа психологии или гносеологии греки уже не могли помочь в принципе, то начальство само определяло "святцы", куда попадали далеко не звезды западноевропейской философии и даже те, кого сейчас могут знать лишь специалисты в области истории философии: Г.Э. Шульце (1808 г. - время "предписания"); Ф.С. Карпе (20-е гг. ХІХ в.); Л. Ботен (Киевский университет, в 30-е гг. ХІХ в.)» [17, с. 27]. В этот период мыслящие люди - Погодин, Шевырев, Грановский, Соловьев, Грот, Лопатин и др. - могли реализоваться как творческие мыслители только вне стен университетов, а именно - в основном в журналах, которые в России заменяли общественные институты.

Только рецепция идей Канта, Шеллинга, Гегеля создает единое интеллектуальное поле, но опять же за пределами университетов. Возникают кружки «"московских любомудров" (В.Ф. Одоевский, М.П. Погодин, С.П. Шевырев, В.Е. Оболенский, А.Н. Муравьев, Н.В. Путята, Д.В. Веневитинов, А.И. Кошелев, И.В. и П.В. Киреевские, Н.В. Рожалин), А.И. Герцена и Н.В. Станкевича (М.А. Бакунин, В.Г. Белинский и др.). В той же среде в близких отношениях пребывали А.С. Хомяков, В.К. Кюхельбекер, А.С. Пушкин, М.М. Нарышкин, М.А. Максимович, Н.И. Надеждин и др.» [17, с. 27]. Далее, как мы знаем, преподавание философии в Московском университете было запрещено, а в 1850 г. были закрыты философские факультеты и кафедры по всей России (как продолжение фразы П.А. Ширинского-Шахматова: «польза от философии не доказана, а вред от нее возможен»), восстановленные только спустя десять лет Александром II. И только в 80-90-е гг. ХІХ в. начинается формирование организационных и коммуникативных структур. Становятся постоянными философские дискуссии, открывается множество философских журналов, создаются общества. Наличие всех этих структур дает возможность вести мировоззренческие баталии разным философским позициям, а соответственно - самобытной публичной философии.

Помимо сосуществования университетской и внеуниверситетской философии, существует проблема (скорее не проблема, а феномен) непрофессиональной философии. «Титульные и культовые для нынешнего понимания российской философии фигуры» [3] - П.Я. Чаадаев, ранние славянофилы, Н.Ф. Федоров, Н.А. Бердяев, Л. Шестов, В.В. Розанов, Вяч. Иванов, П.А. Флоренский, П. Савицкий и др. - не являлись философами ни по специальной подготовке, ни по официальному статусу и роду занятий. В.С. Соловьев был отстранен от университетской кафедры. А ведь они скорее, чем университетские философы, оказали влияние как на развитие интеллектуального сообщества, так и на нашу культуру в целом благодаря такому явлению, как публичная философия в том значении, каким ее наделяет 
У. Липман. Все знают, что просветители XVIIXVIII вв. создают учение (публичную философию) о естественном законе, согласно которому «есть некий закон, и он выше властителя и суверенного народа... выше всего сообщества смертных» $[18$, с. 90$]$. Вера в человеческий разум и его способность произвести универсально значимое знание, включающее в себя ценности, определяют суть западной цивилизации начиная с Римской империи. И эти ценности, «я полагаю, - пишет У. Липман, - не работают в сообществах, которые не придерживаются этой философии» $[18$, c. 90]. Это тоже пример идеологии (как позже будет с университетской революцией), полученной из философии, пример функционального разделения теоретической и публичной философий. Хотя, по мнению Р. Рорти, сегодня дело обстоит иначе, чем в эпоху Просвещения: «В наши дни политика идет впереди, а философия следует за ней по пятам. Сначала выбираются политические взгляды, и лишь потом, да и то если только есть вкус к подобным вещам, начинают искать философскую поддержку» $[19$, с. 13]. Несомненно, что в связи с переходом философствования в публичную сферу важен вопрос еще и политической ангажированности философствующего (в самом общем смысле). Осмелимся предположить, что в сферу публичного взаимодействия в российской философии перешла не академическая философия, а именно непрофессиональная более интересная, самобытная и влиятельная, более интересующаяся проблемами политики и общества. В силу эмоциональной охваченности, неразделенности чувственного и интеллигибельного, литературного обращения с реальностью русская философия реализовалась как своеобразная социальная практика. Именно свободное от регламентов философствование способно породить то богатство мысли, которое предоставил нам Серебряный век и которым мы гордимся.

Таким образом, наша гипотеза о групповом философствовании как способе конструирования идентичности и системы отношений находит подтверждение в истории философии. Цитируем Г. Марселя: «Философствование не есть нечто предпринимаемое исключительно для себя, именно - с целью выйти из состояния неопределенности или смятения путем достижения некоторого внутреннего равновесия, которым сам субъект мог бы удовлетвориться. Напротив, скорее, все происходит так, словно философ разделяет, берет на себя беспокойство или тревогу других людей, которых он не знает лично, но с которыми ощущает себя связанным узами братства» [20, c. 259]. Не будем забывать о том, что с начала $\mathrm{XX}$ века благодаря «лингвистическому повороту» философия все чаще обращается более к тексту, чем к человеку, забывая, что за текстом - человек, и сам человек - тоже текст. Возможно, прав М.Н. Эпштейн, отмечая, что те, «кто работает в гуманитарных профессиях, должны хотя бы частично взять на себя ответственность за этот кризис» [21, с. 18], кризис гуманитаристики, случившийся на наш взгляд, по причине индивидуализации философствования, замыкания философов в сфере познания мира и самопознания.

Коллективное, групповое философствование естественный для человеческого мышления фено- мен, и российская философия здесь не исключение весь наш российский опыт коллективного «сомышления» укоренен в истории европейской философии. В том числе вопрошание и сомнение, ориентированность на социальную проблематику, понимание философии как инструмента воспитания общества и как идеологии. Как общие черты группового философствования российской и европейской интеллигенции также следует отметить стремление к публичности, непримиримость и догматизм, любовь к спорам не ради истины, а ради системы доказательств, некоторую отвлеченность философствования (только вместо споров номиналистов и реалистов у нас - споры западников и славянофилов), дискурсивность. Подчеркнем еще раз в заключение, что философствование, как показывает история философии и образования, наиболее продуктивно тогда, когда оно включено в социальные, культурные и образовательные практики.

\section{СПИСОК ЛИТЕРАТУРЫ:}

1. Ясперс К.Т. Введение в философию. Мн.: Пропилеи, 2000. $191 \mathrm{c.}$

2. Willingham Д. Critical Thinking Why Is It So Hard to Teach? // American Federation of Teachers, 2007, Sammer. P. 8-19.

3. Тульчинский Г.Л. Философствование как самодеятельность, или Персонологическая природа философии // Феномен самодеятельного философствования. СПб.: РФО-СПб ФК, 2005. С. 99-103.

4. Балашов Л. Что такое философия? [Электронный ресурс] // Ноосфера гармоничного развития // http://ikondrashin.narod.ru/rus/intros/levb/whphil.htm.

5. Эпштейн M.H. Filosofia / Л.Г. Тульчинский, М.Н. Эпштейн и др. // Проективный философский словарь. СПб.: Международная кафедра (ЮНЕСКО) по философии и этике СПбНЦ РАН, 2002. 297 с.

6. Азаренко С.А. Топологии сообщества. Казань: Познание, 2014. 228 с.

7. Рассел Б. История Западной философии: в 2 т. Т. 1. М.: МИФ, 1993. 509 c.

8. Татаркевич В. История философии. Античная и средневековая философия. Пермь: Изд-во «Пермский государственный университет», 2000. 482 с.

9. Лосев А.Ф. История античной философии в конспективном изложении. М.: ЧеРо, 1998. 192 с.

10. Шкуратов В.А. Интеллигенция в проекте современности // Логос, 2005. № 6. С. 243-252.

11. Реале Д. Западная философия от истоков до наших дней: Средневековье (от Библейского послания до Макиавелли) [Электронный ресурс] // Библиотека «Полка букиниста»: Значимые книги отечественных и зарубежных авторов / Д. Реале, Д. Антисери. http://society.polbu.ru/reale_westphilomiddle/ ch28_i.html.

12. Шкуратов В.А. Фазы парадигмы (эскиз психолого-исторической эпистемологии). Ч. 1 // Российский психологический журнал. 2006. Т. 3, № 2. C. 61-80.

13. Агапов М.Г., Корандей Ф.С. Университетские интеллектуальные сообщества: интерактивные ритуалы и модели сборки // Вестник археологии, антропологии и этнографии. 2013. № 4 (23). С. 133-141.

14. Шнайдер У.И. Преподавание философии в немецких университетах в XIX веке // Логос. 2004. № 3-4 (43). C. 61-90. 
15. Collins R. Interaction Ritual Chains // Princeton \& Oxford: Princeton Univ. Press, 2004. 464 p.

16. Нехаев А. Академический феодализм, университетская революция и фигура философа // Вестник Томского государственного университета. 2014. № 378. С. $82-89$.

17. Красиков В.И. Университетская философия в России XIX века: особенности и модель эволюции // Вестник Томского государственного университета. Философия. Социология. Политология, 2009. № 3 (7). C. 25-33.

\section{PHILOSOPHIZING AS A PEDAGOGICAL TECHNIQUE: EUROPEAN AND RUSSIAN EXPERIENCE}

(C) 2017

Bakshutova Ekaterina Valerievna, doctor of philosophical sciences,
associate professor of General and Social Psychology Department
Samara State University of Social Sciences and Education (Samara, Russian Fede

Bakshutova Ekaterina Valerievna, doctor of philosophical sciences,
associate professor of General and Social Psychology Department
Samara State University of Social Sciences and Education (Samara, Russian Fede

Bakshutova Ekaterina Valerievna, doctor of philosophical sciences,
associate professor of General and Social Psychology Department
Samara State University of Social Sciences and Education (Samara, Russian Federation) М., 2001. С. 254-267.
18. Липман У. Публичная философия. М.: ИдеяПресс, 2004. 160 c.

19. Рорти Р. Демократия и философия // Неприкосновенный запас. 2007. № 6 (56). С. 6-17.

20. Марсель Г. Ответственность философа в современном мире // Путь в философию. Антология.

21. Эпштейн М.Н. От знания - к творчеству. Как гуманитарные науки могут изменять мир. М.; СПб.: Центр гуманитарных инициатив, 2016. 480 с.

Abstract. The following paper assumes and proves that philosophizing is one of the most effective pedagogical technologies for the development of the individual and society, which actualizes the possibility and ability to generate new knowledge about the world and man, which, in turn, largely determine the human worthiness of intellectual and real social communications, including educational ones. It is shown that knowledge brings tangible benefits when it becomes an object and a part of public intellectual communication, including philosophy, pedagogy and social practices. The author's interpretation of the history of philosophizing in topos of intellectual discussions is presented: the city - the monastery - the city - the university, the comparative analysis of the philosophizing principles of the western and Russian philosophical schools is generalized. The specifics of philosophizing in the Russian intellectual space, including the educational one, are revealed, its exclusion from the school and university into free creative communities - a circle or salon. Differences in the pedagogical orientation of European and Russian philosophical schools and traditions are described, when in the European experience «tops» acted as «learners», and in Russia philosophizing as a pedagogical technology in the XIX - early XX centuries was oriented to «bottoms», but in any case it was always practical. The assumption is made that in both cases the limitation of the educational audience is unnecessary, which is especially evident in the current conditions of the accessibility of education, from which quite often free philosophizing is emasculated.

Keywords: philosophizing; individual and collective philosophizing; pedagogical technology; educational space; public philosophy; philosophizing toposes; creation of knowledge; dogmatism and authoritarianism in the school of thought; freedom of intellectual activity; social significance of the humanities.

УДК 37.015.3:177

\section{ЖИЗНЬ НА ОСНОВЕ ЗОЛОТОГО ПРАВИЛА НРАВСТВЕННОСТИ КАК ИДЕЯ НРАВСТВЕННОГО ВОСПИТАНИЯ УЧАЩИХСЯ}

(C) 2017

Бездухов Владимир Петрович, доктор педагогических наук, профессор, член-корреспондент РАО, профессор кафедры педагогики и психологии

Позднякова Оксана Константиновна, доктор педагогических наук, профессор, член-корреспондент РАО, профессор кафедры педагогики и психологии

Самарский государственный сочиально-педагогический университет (2. Самара, Российская Федераџия)

Аннотащ̧ия. В статье приводятся доказательства важности и необходимости нравственного воспитания учащихся. Показывается, что нравственное воспитание должно базироваться на идее, которая рождается во взаимопереходах мысли (субъективное) и мыслимого (объективное). Выявляется, что идея указывает на недостаток жизни, состоящий в том, что понятия «добро», «благо», «человечность» и реальность, в которой живет размышляющий о жизни человек, соответствуют друг другу не истинным образом. Показывается, что все предыдущее развитие этического и педагогического мышления содержит в себе доказательство идеи добра. Раскрывается, что идея как системообразующее звено перехода от ценностей «для себя» в ценности «для другого» является вершиной в иерархии норм. Предъявляется идея нравственного воспитания учащихся - жизнь на основе золотого правила нравственности, которое как ценность является звеном перехода от ценностей «для себя» в ценности «для другого», как норма нормализует взаимоотношения и взаимодействия человека с миром и людьми. Показывается различие между ценностью и нормой, заключающееся в том, что ценность является внутренним регулятором деятельности и поведения, а норма внешним регулятором. Раскрывается, что реализация учителем золотого правила нравственности, содержащего в себе требуемое, должное, предписательное, способствует упорядочиванию смыслов жизни, становящихся ее ориентирами; нормализации взаимодействия ученика с миром и с людьми. Показывается, что в процессе взаимодействия в 